\title{
пСИХОЛогИЯ
}

DOI: $10.17805 /$ trudy.2018.1.1

\section{ОТ КАФЕДРЫ ПИОНЕРСКОЙ РАБОТЫ ДО КАФЕДРЫ ОБЩЕЙ ПСИХОЛОГИИ И ИСТОРИИ ПСИХОЛОГИИ (ИЗ ИСТОРИИ ФАКУЛЬТЕТА ПСИХОЛОГИИ, ПЕДАГОГИКИ И СОЦИОЛОГИИ МОСКОВСКОГО ГУМАНИТАРНОГО УНИВЕРСИТЕТА)}

\author{
Е. В. Гурова \\ Московский гуманитарный университет
}

\begin{abstract}
Аннотация: В статье рассматривается история кафедры общей психологии и истории психологии Московского гуманитарного университета, которая ранее называлась кафедрой психологии, педагогики и детского движения. Деятельность кафедры по подготовке психологических кадров явилась одним из оснований создания факультета психологии, ныне - факультета психологии, педагогики и социологии МосГУ.

ключевые слова: кафедра пионерской работы; Высшая комсомольская школа; Институт молодежи; Московский гуманитарный университет; кафедра психологии личности и педагогики; кафедра психологии развития и акмеологии; история психологии

\section{FROM THE DEPARTMENT OF PIONEERS' WORK TO THE DEPARTMENT OF GENERAL PSYCHOLOGY AND THE HISTORY OF PSYCHOLOGY (ON THE BACKGROUND OF THE FACULTY OF PSYCHOLOGY, PEDAGOGY AND SOCIAL SCIENCE AT MOSCOW UNIVERSITY FOR THE HUMANITIES)}

\author{
E. V. Gurova \\ Moscow University for the Humanities
}

\begin{abstract}
The paper gives the background of the Department of General Psychology and the History of Psychology at Moscow University for the Humanities, which was formerly called the Department of Psychology, Pedagogy and Children's Movement. The department's work on training psychologists was one of the grounds for the establishment of the Faculty of Psychology, which is now called the Faculty of Psychology, Pedagogy and Social Science at MosGU.

Keywords: Department of Pioneers' Work; Higher School of Komsomol; Institute of Youth; Moscow University for the Humanities; Department of Personality Psychology and Pedagogy; Department of Development Psychology and Acmeology; history of psychology
\end{abstract}

Факультету психологии, педагогики и социологии Московского гуманитарного университета в 2018 году исполняется 25 лет - четверть века. Юбилейные даты всегда заставляют оглянуться назад, вспомнить, что было в начале пути. В такие дни коллектив переживает удивительное состояние «Мы» - сплоченности и причастности к истории своего становления. Официально она начинается с 1 марта 1993 г., когда был подписан приказ ректора Института молодежи о создании факультета психологии. Начинался факультет с кафедры психологии, педагогики и детского движения, истоки которой тесно связаны с историей деятельности Высшей комсомольской школы (ВКШ) при ЦК ВЛКСМ (1969). 
В структуре ВКШ была кафедра пионерской работы. Ее возглавлял в то время канд. пед. наук В. В. Лебединский. На кафедре работали канд. пед. наук З. А. Ходоровская, канд. пед. наук Е. Г. Глух, канд. пед. наук С. Н. Ганичева, канд. пед. н. В. Н. Брусенцова, канд. пед. наук В. И. Николаев и другие. Среди них были выпускники аспирантуры Академии педагогических наук 一 канд. пед. н. Е. П. Белозерцев и канд. пед. н. А. В. Иващенко. Преподаватели кафедры осуществляли психологопедагогическую подготовку студентов на факультетах истории и коммунистического воспитания, комсомольской работы, подготовки работников зарубежных союзов молодежи, а также слушателей отделения подготовки и переподготовки кадров для работы в комсомольских и пионерских организациях.

В начале 70-х годов XX столетия кафедра пионерской работы объединилась с секцией педагогики и психологии, которую возглавляла канд. пед. наук Э. Ш. Камалдинова, и получило новое название - кафедра педагогики и пионерской работы. В 1975 г. на факультете истории и коммунистического воспитания и факультете подготовки работников зарубежных союзов молодежи ВКШ в учебный план впервые был введен курс «Основы психологии». Его читали д-р психол. наук, проф. Н. И. Рейнвальд (Российский университет дружбы народов), канд. психол. наук И. В. Дубровина (Психологический институт АПН СССР - ныне Психологический институт Российской академии образования), канд. психол. наук Н. Ф. ШляХта из того же института. После непродолжительной стажировки к чтению курса был привлечен и канд. пед. наук А. В. Иващенко, который в 1980 г. стал заведующим этой кафедрой.

По его инициативе и поддержки ректората в 1982 г. в аспирантуре ВКШ была открыта подготовка специалистов по специальности 13.00 .01 - теория и история педагогики. Спустя три года приказом ВАК СССР от 20 марта 1985 г. № 86-в утвержден состав специализированного совета К. 150.00.04 в ВКШ при ЦК ВЛКСМ. Специализированному совету было разрешено проводить защиту диссертаций на соискание ученой степени кандидата наук по специальности 13.00.01 - теория и история педагогики. Председателем совета был утвержден А. П. Зиновьев, доктор наук, профессор, проректор ВКШ. В состав совета вошли д-р пед. наук В. В. Лебединский, канд. пед. наук 3. А. Ходоровская, канд. пед. наук О. И. Зотова, д-р филолог. наук В. Е. Ярнатовская, канд. пед. н. В. В. Дружинин, д-р пед. наук А. В. Иващенко, д-р пед. наук Р. Г. Гурова, канд. пед. наук Г. П. Черный и др. Прошли первые защиты кандидатских диссертаций.

В эту аспирантуру в 1987 г. я поступила на учебу на очное отделение. Решение продолжить свое обучение в аспирантуре было продиктовано необходимостью выбора дальнейшего профессионального пути. До этого я несколько лет проработала в школе учителем, в 1978 г. была избрана секретарем Свердловского районного комитета комсомола (г. Москва). На этой должности я трудилась до 1987 г. Моя комсомольская карьера подходила к завершению в связи с возрастом, надо было определяться, что делать дальше. Знала, что есть аспирантура в Высшей комсомольской школе, но поступать туда имели возможность только работники городских, областных, краевых комсомольских организаций. Тем не менее, приехала на собеседование, по итогам которого была допущена к экзаменам.

Было непривычно оказаться уже в зрелом возрасте в качестве учащегося 
дневной формы обучения. Учиться, получать стипендию в размере оклада с предыдущего места работы, заниматься всего лишь два дня в неделю, быть частью аспирантского братства.... Это были годы, которые вспоминаются с особой теплотой. Большую часть времени мы проводили в библиотеках. Нас очень быстро подключили к работе кафедры, мы присутствовали на всех заседаниях, позднее привлекли к проведению занятий для слушателей ВКШ. Подготовка и переподготовка кадров комсомольских и пионерских организаций продолжалась в ВКШ вплоть до сентября 1991 г. Шли защиты диссертационных исследований аспирантов старших курсов. Присутствие на заседаниях диссертационного совета было для нас обязательным, да и иначе не могло быть, мы были задействованы в подготовке любой защиты. Встреча оппонентов, подготовка 511 аудитории 3-го учебного корпуса, в которой проходили защиты, комнаты отдыха для членов диссертационного совета и т. д. Сама процедура защиты исследований для нас имела обучающий характер.

В 1990 г. Высшая комсомольская школа при ЦК ВЛКСМ была преобразована в Институт молодежи ЦК ВЛКСМ и Госкомтруда СССР. Это было очень непростое время социально-политических и экономических преобразований. Сложная обстановка была и внутри Института молодежи. В сентябре 1991 г. прошел XXII Чрезвычайный съезд ВЛКСМ, где организация объявила о своем самороспуске. Институт молодежи оказался свободным от ведомственной принадлежности, но без финансирования. Однако, главным явилось то, что институт был сохранен как целостная структура. Открывались и новые возможности, в России уже стартовал образовательный бизнес. Но в коллективе было неспокойно. Менялся статус организации, ее учредители. Денег для содержания огромного хозяйства не хватало. На территории стали появляться всевозможные ассоциации, центры, совместные предприятия. Помещения сдавались в аренду. Учебный процесс не приносил прибыли. Прежнее содержание образования, которое давало ВКШ, оказалось невостребованным. Ректорат Института молодежи, его подразделения, кафедры пытались искать новые формы существования.

Именно в этот период в Институте молодежи был открыт факультет послевузовского образования с отделениями «Психология», «Социология», «Журналистика». Руководителем факультета была назначена Л. М. Чижова, заместителем А. Л. Кузьмина.

Поскольку в Москве подобные факультеты были открыты практически во всех педагогических вузах, а также в МГУ им. М. В. Ломоносова (в обществе заметно возрос статус психологической науки, стала активно развиваться практическая психология), было трудно выдерживать конкуренцию. Было принято решение для организации набора и учебного процесса использовать материальную базу института, его общежития, а также те связи с регионами, которые сложились за годы функционирования Высшей комсомольской школы.

По заданию ректората летом 1990 г. наши ведущие профессора А. В. Иващенко и А. И. Крупнов отправились в командировку в Алтайский край и Читинскую область. Вместе с руководителями отделов народного образования г. Барнаула и г. Читы через собеседование они набирали будущих слушателей. В Москву приехали более 70 человек, по качественному составу это были разновозрастные пе- 
дагоги среднеобразовательных школ. 1 октября 1990 г. отделение психологии начало свою работу. Слушателям предстояло учиться 9 месяцев.

В период реорганизации ВКШ в Институт молодежи (1990 г.) кафедра педагогики и пионерской работы была также реорганизована, она получила новое название кафедра психологии, педагогики и детского движения. Изменился и кадровый состав кафедры. Многим было предложено уйти на заслуженный отдых в связи с пенсионным возрастом. Из штатных преподавателей в 1990 г. остались работать А. В. Иващенко, В. А. Курганова, Г. В. Володина, Э. Ш. Камалдинова, В. В. Лебединский, Л. В. Кузнецова, из молодежи - В. Н. Выговская, Л. А. Калмыкова, А. П. Покровская. Было также предложено остаться на кафедре аспирантаммосквичам, которые в тот год защитили диссертации: Н. Н. Седова, Т. П. Голубкова, Т. Н. Онипко, Н. Д. Левшина. Среди них оказалась и я.

Практически все сотрудники кафедры, за исключением А. В. Иващенко, Л. А. Калмыковой, читали педагогические курсы. Перед коллективом была поставлена задача - включиться в разработку новых учебных курсов психологического направления. Для многих это оказалось сложной проблемой, т. к. они читали курсы, далекие от психологии. Кроме того была и нестабильная обстановка в самом институте. Ряд преподавателей, в том числе и молодые специалисты, ушли в поисках лучшего места.

Мне поручили разрабатывать курс по возрастной психологии, назначив при этом наставника. Целый год я посещала лекции канд. психол. наук Н. Ф. Шляхта, вела семинары. Вместе с ней ездила в МГУ слушать этот курс у профессора Л. Ф. Обуховой. Делала свою первую учебную программу, разрабатывала собственный лекционный курс.

Собственных сил кафедры явно было не достаточно, чтобы обеспечить выполнение учебного плана. На помощь пришли профессора Российской академии государственной службы (РАГС), академии ФСБ, РУДН. В Институт молодежи была приглашена группа психологов: д-р психол. наук А. А. Деркач, д-р психол. наук В. Г. Крысько, д-р психол. наук Е. Н. Резников, канд. психол. наук А. А. Кокарев. Продолжал работать д-р психол. А. И. Крупнов.

Начало движения в психологическую науку было положено. В последующие года «спецфак», как его называли внутри института, набирал силу. Состоялись новые наборы, отрабатывались программы, совершенствовалось содержание курсов, изучалась практика работы подобных факультетов в вузах Москвы и Ленинграда, расширялись связи кафедры с психологическими факультетами и научными организациями.

Решался главный вопрос - кадры. Пришли работать д-р психол. наук, проф. И. И. Ильясов, д-р психолог. наук, проф. Т. Ф. Базылевич, канд. мед. наук, проф. Н. Н. Самко. Также пришла работать группа молодых преподавателей - выпускников МГУ - канд. психол. наук Т. С. Леви, канд. психолог. наук Л. Б. Шнейдер, Г. И. Марасанов, В. Н. Шатило и другие.

1 июля 1992 г. кафедра психологии, педагогики и детского движения поменяла свое название, став кафедрой психологии и педагогики. От детского движения пришлось отказаться - в содержании работы кафедры его не оказалось. Всесоюзная пионерская организация им. В. И. Ленина прекратила свое существование, как и комсомол. 
Факультет послевузовского образования позволил кафедре отработать учебные планы по направлению «Психология», подобрать кадры. Возникла уверенность, что институту и кафедре по силам открытие полноценного факультета. Материальная база есть, учебные планы готовились, преподаватели подобраны. Нужна была поддержка психологического сообщества. В Москве было два психологических института: Институт психологии РАН и Психологический институт PAO, а также психологический факультет МГУ. Переговоры с МГУ ничего не дали. По всему предыдущему опыту работы ВКШ и Института молодежи, конечно, ближе был ПИ РАО, но после консультаций А. В. Иващенко с известными психологами д-ром психол. наук К. А. Абульхановой-Славской и д-ром психол. наук А. А. Деркачом выбор был сделан в пользу Института психологии Российской академии наук.

А. В. Иващенко вспоминает, как весной 1992 г. позвонил директору Института психологии, профессору А. В. Брушлинскому. Лично с ним на тот момент он не был знаком. Представился, попросил принять по вопросу развития на базе Института молодежи психологического направления. Встреча состоялась через два дня. Было страшно говорить о создании на базе политизированного до недавнего времени вуза психологического факультета. Многим эта идея казалась «бредовой», что-то из области фантастики. Но были конкретные дела, свидетельствующие о возможности этого. Два года работает факультет послевузовского образования; учебные планы сверстаны; есть возможность обеспечить выполнение содержания специальности 020400 «Психология», кадров своих не хватает, но привлекаем специалистов из других вузов: РАГС, академии ФСБ, РУДН; есть аспирантура по специальностям 13.00.01 - теория и история педагогики, 19.00.05 - социальная психология, 19.00.11 - психология личности; есть аспиранты -57 человек, в том числе и по психологии (среди них были уже первые выпускники факультета послевузовского образования) и есть научные руководители по психологическому направлению; переутвержден новый состав диссертационного совета К.150.00.04, которому разрешено проводить защиту диссертаций на соискание ученой степени кандидата наук по вышеуказанным специальностям; есть материальная база, учебные корпуса, общежитие, библиотека, полиграфическая база.

Именно об этом и рассказывал А. В. Иващенко на встрече с А. В. Брушлинским. Как вспоминает А. В. Иващенко, А. В. Брушлинский внимательно выслушал, пообещал поддержать, помочь, по необходимости даже кадрами. Посоветовал обратить внимание на своего молодого сотрудника - канд. психол. наук Ю. Н. Олейника. Так в профессорско-педагогическом составе кафедры психологии и педагогики появился Ю. Н. Олейник. Его энергия, энтузиазм и увлеченность, знания, связи в научном психологическом сообществе сыграли свою роль. Вместе с ним в коллектив пришли очень многие сотрудники ИП РАН.

Началась активная подготовительная работа по открытию факультета психологии. Готовились необходимые документы, велись предварительные разговоры с членами ректората, учебным отделом, руководителями факультетов социальной работы (канд. филос. наук Т. А. Русакова) и послевузовского образования (С. М. Чижова). Понятно, что приходилось забирать из их структур студентов, с чем вряд ли так просто будет соглашаться руководитель. Надо было доказывать необходимость и перспективы этого шага. Шла активная агитация среди студен- 
тов факультета социальной работы 2 и 3 курса о переходе некоторых из них на новый, открывающийся факультет психологии. Открытие факультета поддерживали проректор В. Г. Никулин, зав. учебно-методическим управлением И. М. Лаврененко - именно они в то время определяли учебную политику института.

На момент открытия факультета на кафедре психологии и педагогики работало около 50 преподавателей. Все мы размещались в 417 аудитории 3-го учебного корпуса. Большинство из них были штатные совместители. В феврале 1993 г. состоялся расширенный ректорат, где В. Г. Никулин и А. В. Иващенко докладывали о возможности открытия психологического факультета на базе Института молодежи. И уже 1 марта 1993 г. вышел приказ об открытии факультета психологии. Руководителем факультета на период его создания (до выборов декана в соответствии с нормативными документами) был назначен А. В. Иващенко, его заместителем Ю. Н. Олейник. Это было начало пути...

Создание факультета психологии на базе бывшей комсомольской школы было оценено в психологических кругах как некий вызов. Да и внутри Института молодежи некоторые неоднозначно отнеслись к этому событию. Но с каждым годом работы факультета росла уверенность, что сделан правильный выбор, ориентируясь на укрепление связей с ИП РАН. Это было обоюдно выгодное продуктивное сотрудничество. Руководство Института молодежи сумело заинтересовать ученых, создать необходимые условия. Сотрудники многих лабораторий ведущего исследовательского института страны стали преподавателями факультета психологии. Они начали осваивать новую педагогическую профессию на нашей площадке, но параллельно создали структуру и в Институте психологии. Это Высший психологический колледж, который потом был преобразован в Высшую школу психологии при ИП РАН.

Факультет не мог состоять из одной кафедры, и 30 июня 1994 г. вышел приказ по Институту молодежи № 332к за подписью И. М. Ильинского о создании на базе кафедры психологии и педагогики с 1 июля 1994 г. трех кафедр: кафедры психологии личности и педагогики; кафедры общей психологии и истории психологии; кафедры социальной и этнической психологии.

Кафедра психологии и педагогики, согласно этому приказу, с 1 сентября 1994 г. ликвидировалась. Штатных сотрудников разделили пропорционально, вопрос кто возглавит новые коллективы не стоял, было все очевидным. Кафедру психологии личности и педагогики возглавил д-р пед. наук А. В. Иващенко. Его заместителем назначена канд. пед. наук Л. В. Щербакова. В штатный состав кафедры вошли: д-р пед наук, проф. В. А. Лебединский, канд. пед. наук В. Д. Иванов, д-р филос. наук Э. Ш. Камалдинова, канд. психол. наук Т. С. Леви, канд. психол. наук В. Н. Линде. На условиях штатных совместителей на кафедре работали д-р филос. наук К. А. Абульханова-Славская, д-р психол. наук А. А. Деркач, д-р психол. наук А. И. Крупнов, д-р психол. наук Т. Ф. Базылевич, д-р психол. наук Р. Г. Гурова. Привлекались и специалистов из других вузов. Аудитория № 417 была закреплена за новой кафедрой.

Заведующим кафедрой общей психологии и истории психологии был назначен канд. психол. наук Ю. Н. Олейник, я стала его заместителем по учебной работе. В штатный состав кафедры вошли канд. психол. наук, и.о. доц. В. В. Бол- 
тенко, ст. преп. Е. В. Андрианов. В состав штатных совместителей были зачислены сотрудники ИП РАН д-р психол. наук, проф. В. А. Барабанщиков, канд. психолог. наук, ст. н. с. В. А. Кольцова, д-р психол. наук проф. В. Ю. Крылов, канд. психол. наук Т. Н. Савченко, канд. психол. наук, ст. н. с. Ф. Е. Иванов, канд. психол. наук, ст. н. с. С. Л. Новоселова из МГУ, а также канд. мед. наук Н. Н. Самко. На условиях почасовой оплаты пришли работать на кафедру канд. психол. наук, ст. н. с. Г. Г. Филиппова, И. Б. Незавибатько. Позднее на кафедре стали работать д-р психол. наук А. А. Митькин (ИП РАН), А. М. Матюшкин (ПИ РАО). Кафедре была выделена аудитория № 419, которую предстояло оборудовать.

Открытие кафедры социальной и этнической психологии на факультете состоялось благодаря заведующему лабораторией социальной психологии ИП РАН в то время еще канд. психол. наук А. Л. Журавлеву и его сотрудникам. А. Л. Журавлев был назначен заведующим кафедрой, а его заместителем по учебной работе - канд. пед. наук В. Н. Выговская. В качестве преподавателей в штате были включены канд. психол. наук В. П. Левкович, канд. психол. наук О. В. Лунева, на условиях штатных совместителей: д-р психол. наук, проф. Е. Н. Резников, канд. психол. наук А. А. Обознов, канд. психол. наук С. Е. Поддубный, канд. психол. наук Е. Д. Дорофеев, канд. психол. наук В. А. Хащенко, д-р психолог. наук В. Г. Крысько. Позднее в работу кафедры включились такие специалисты, как канд. психолог. наук А. Б. упрейченко, канд. психол. наук В. П. Позняков, д-р психолог. наук Т. П. Емельянова, д-р псих. наук А. А. Грачев и др. Многие сотрудники кафедры в последующем успешно защитили докторские диссертации.

Тесные контакты с лабораториями Института психологии РАН, несомненно, повысили научный и научно-методический статус факультета. Впоследствии д-р псих. наук профессор А. Л. Журавлев уже в статусе директора ИП РАНа станет научным руководителем факультета. С 2003 г. он возглавлял диссертационный совет Д.150.004.05. по защите докторских и кандидатских диссертаций, в котором я исполняла обязанности ученого секретаря. Это взаимодействие многому меня научило.

Помимо уважаемых и известных в психологических кругах ученых на факультет пришло работать много молодежи - аспирантов и выпускников спецфака. Среди них В. С. Агапов, Г. П. Иванова, Б. Б. Айсмонтас, Л. Е. Сикорская, Е. Н. Корнева, И. С. Алексеенко, Е. С. Соколова (Балабанова). И. Р. Кислова (Федоркова), Т. А. Казанцева. Выросли и студенты, которые после обучения в аспирантуре и успешной защиты диссертаций, стали преподавателями (Е. Н. Сиващенко, П. В. Гостева, Н. Е. Серенко (Коренкова), М. В. Муконина, И. А. Хватов, Н. И. Федотова). Вернулись на факультет уже в качестве преподавателей студенты А. В. Полянский, Е. Овчинников.

На кафедре общей психологии и истории психологии я проработала недолго - до 1996 г. Как только организационно кафедра укрепилась, А. В. Иващенко предложил вернуться на кафедру психологии личности и педагогики. Просьбу мотивировал тем, что проще будет руководить диссертационным советом: ему как председателю, мне - как ученому секретарю.

Решение принимала тяжело. С одной стороны, на кафедре общей психологии и истории психологии без базового психологического образования чувствовала себя не очень уверенно. С другой - не могла принять стиль руководства кафедрой Ю. Н. Олейника. Работа в школе, потом в комсомоле, затем на традиционной 
академической кафедре сформировали у меня свое видение, как должна работать эта структурная единица вуза. Я - за четкую организованность, ежемесячные заседания, коллективные обсуждения планов, отчетов, нагрузки и т. д., Ю. Н. Олейник - за творчество и свободу. Тем не менее, мы успешно работали вместе, каждый отвечал за свой участок, особых конфликтов не было. Мое отношение к Ю. Н. Олейнику как человеку было и остается позитивным.

Со стороны А. В. Иващенко давление усиливалось. Чувство долга перед научным руководителем, который ввел меня не только в мир науки, но и помог моему становлению как педагогу высшей школы, определило мое решение.

В октябре 1996 г. я перешла на его кафедру и была назначена его заместителем по научной работе. Это был уже другой коллектив, и мне снова нужно было в нем адаптироваться. Кафедра была представлена очень разносторонними специалистами, занимающихся изучением подчас существенно расходящихся, трудно сводимых к общему знаменателю научных проблем. Но общая кафедральная тема была найдена: проблема формирования и развития личности в новых социальных условиях жизни общества. Каждый преподаватель нашел свою нишу в рамках такой формулировки.

Шло время, менялись руководители факультета, неизменными оставались руководители кафедр. Но эта постоянство было нарушено. В феврале 2003 г. после очередного заседания совета, где в адрес А. В. Иващенко прозвучала критика со стороны проректора Б. А. Ручкина, А.В Иващенко подал заявление об уходе. Можно только догадываться о драматичности этого события для человека, который более 20 лет проработал в организации. Это шаг нарушил привычный ритм работы кафедры, коллектив был обескуражен. Настолько мы уже привыкли к своему руководителю, к его стилю, а впереди - неизвестность.

Заведующим кафедрой назначили д-ра пед. наук Р. Г. Резакова, который недавно пришел в Московскую гуманитарно-социальную академию (так стал называться Институт молодежи) после защиты докторской диссертации по педагогике и короткий срок успел поработать в качестве заместителя декана факультета психологии. Была принята в штат канд. психол. наук Л. Е. Сикорская, она в последующем стала его заместителем по учебной работе.

В марте 2004 г. в университете была создана новая кафедра педагогики и психологии высшей школы. Возглавил ее д-р пед. наук В. А. Ситаров. В целях повышения качества подготовки специалистов на факультете психологии, исключения дублирования в содержании обучения, укрепления кадрового потенциала 20 апреля 2004 г. вышел приказ по Московскому гуманитарному университету № 414к о ликвидации с 20 июня 2004 г. кафедры психологии личности и педагогики. Всем преподавателям кафедры предложили написать заявление об уходе по собственному желанию.

Ректорат сделал попытку создать новую кафедру с новым руководителем. С 21 июня 2004 г. начала функционировать новая кафедра психологии развития и акмеологии под руководством д-р психол. наук О. Г. Носковой, профессора кафедры психологии труда и инженерной психологии МГУ им. М. В. Ломоносова. Все штатные сотрудники ликвидированной кафедры были зачислены на работу, кроме канд. пед. наук Л. Н. Щербаковой. Осталась на кафедре после успешной защиты 
диссертации канд. психол. наук Е. Г. Суркова. Р. Г. Резаков был оформлен переводом на кафедру психологии и педагоги высшей школы и в дальнейшем ушел из организации.

Сотрудники кафедры активно включились в разработку методических материалов по читаемым курсам. Были изданы сборники тестов по психологии развития с грифом УМО (Гурова, 2005), по клинической психологии (Гребенникова, 2007).

По приглашению О. Г. Носковой в коллектив кафедры вошли канд. психол. наук Н. Д. Даровская (факультет психологии МГУ), О. Б. Ломакина. О. Г. Носкова пыталась привлечь к работе кафедры и других сотрудников МГУ. Так были приглашены д-р психол. наук О. А. Карабанова, д-р психол. наук Н. С. Пряжников, канд. психол. наук Е. И. Захарова. Но, к сожалению, их сотрудничество с кафедрой психологии развития и акмеологии было непродолжительным.

Вместе с тем, О. Г. Носковой удалось определить общую тему исследования для кафедры: «Психологические проблемы развития и коррекции личности в современных условиях». Под ее руководством был выполнен грант РГНФ по исследовательскому проекту «Особенности личностного и профессионального самоопределения детей-сирот, воспитывающихся в государственных учреждениях, в контексте современной социально-культурной ситуации в России» (Гребенникова, Федотова, 2010). За время ее работы на кафедре были подготовлены и защищены 8 диссертационных исследований, из них две работы выполнены под ее руководством (Ю. А. Бурмакова и А. Г. Ниазашвили).

В 2008 г. О. Г. Носкова добровольно покинула свой пост. Мы снова остались без руководителя, но это было уже привычным чувством, нам оставалось ждать.... Вместе с О. Г. Носковой ушла и Н. Д. Даровская, О. Б. Ломакина осталась работать на условиях почасовой оплаты, позже перешла на кафедру общей психологии и истории психологии, на которой успешно работает и до настоящего времени.

Для объединения коллектива кафедры много сделала канд. психол. наук Е. Г. Суркова. Она оказалась не только успешным преподавателем, но и отличным организатором туристических поездок. Вместе с ней мы объездили все большое и малое Золотое кольцо России, кроме этого были в Казани, Смоленске, на Валдае и в Новгороде, Санкт-Петербурге, Вологде, Туле, Рязани, в Этномире (г. Боровск). К нам присоединялись и сотрудники других кафедр. Экскурсионные программы всегда были необычными. Елене Германовне удавалось найти самобытных экскурсоводов, знающих и любящих свой край. Часто это были экскурсоводы-любители, раскрывающие не только официальную историю своего города или поселения. Были и удивительные творческие встречи. Например, в Суздале мы были потрясены пением известного звонаря Спасо-Евфимиевском монастыря Валерия Гаранина. В Костроме для нас пел хор Троицого собора Ипатьевского монастыря. Были мастер-классы у художников в Переславле, рисовали Жар-птиц в Палехе.

Как преподавателя Е. Г. Суркову любили студенты, она отличалась творческим подходом к делу, читала такие практико-ориентированные курсы как арттерапия, проективные методы исследования личности, психологическое консультирование, психодиагностика. Позднее, у нее вышел замечательный учебник по проективным методам в психодиагностике (Суркова, 2018). Вместе с ней мы 
изучали проблему творчества (Гурова, Суркова, 2012).

Новым заведующим кафедрой психологии развития и акмеологии была назначена наша коллега, д-р психол. наук Г. Г. Филиппова, профессор кафедры общей психологии и истории психологии. Мы хорошо знали Галину Григорьевну как профессионала и как человека. За долгие годы работы в структуре университета это был пятый заведующий кафедрой, с которым мне пришлось сотрудничать. Я была рада этому назначению. Е. Г. Суркова была назначена ее заместителем по учебной работе, я отвечала за работу с аспирантами. Мы все старались помочь новому заведующему, и с ее стороны мы видели желание работать. Г. Г. Филиппова сразу очень четко выстроила регламент деятельности кафедры и каждого из нас, и мы приняли это безоговорочно. Мы знали дни заседаний кафедры на семестр, коллективно обсуждались планы, отчеты, учебную нагрузку. Г. Г. Филиппова открыто информировала нас о проблемах кафедры, факультета, мобилизуя при этом коллектив на их решение. Это был, действительно, демократический стиль руководства, и мы старались не подводить руководителя, понимая, что он не только несет ответственность за кафедру, но и заботиться о каждом из нас.

К большому сожалению, кафедра под руководством Г. Г. Филипповой просуществовала недолго до 2011 г. и была расформирована, очевидно, в целях экономии средств университета. Так закончилась краткая история кафедры психологии развития и акмеологии.

Но коллектив сохранился, с сентября 2011 г. мы работаем на кафедре общей психологии и истории психологии, руководит которой бессменно вот уже 24 года Ю. Н. Олейник. Здесь другая атмосфера, стиль его руководства коллективом за эти годы не изменился. Мне и Г. Г. Филипповой он был знаком, но другим коллегам пришлось адаптироваться, что произошло не сразу. Теперь я понимаю, что, может быть, именно этот либерализм помогает Ю. Н. Олейнику удерживать на кафедре преподавателей при условии весьма скромной заработной платы в вузе. Долго держались доктора наук, ведущие сотрудники ИП РАНа, но они постепенно уходят, как и ряд других наших преподавателей. К сожалению, нагрузка растет, для ее выполнения ежегодно приходится осваивать новые курсы.

Е. Г. Суркова сейчас работает в сфере туризма. Свою психологическую практику она сохранила. Последним вкладом Е. Г. Сурковой в отечественную психологию стало создание уникального учебника «Психология семьи» (Суркова, 2014). Она выступила с инициативой, которая была поддержана Г. Г. Филипповой, Н. В. Гребенниковой, Е. В. Гуровой, Н. И. Федотовой и др. Учебник получил гриф УМО. Это совместная работа показала, что мы можем работать в команде, коллективно решать сложные задачи, мобилизоваться и доводить начатое дело до конца. По содержанию это уникальное издание, помимо традиционных вопросов, касающихся жизни семьи, ее функционирования, в нем раскрываются этнические аспекты и онтогенетические механизмы формирования семейных моделей, а также вопросы отношений с престарелыми членами семьи и проблемы семьи, имеющей детей с нарушениями развития. Такой подход особенно актуален в условиях активного распространения межэтнических сообществ, а также в ситуации распада традиционных семейных моделей и исчезновения традиционных внутрисемейных институтов трансгенерационной передачи семейного опыта. 
Также покинул наш коллектив канд. психол. наук Н. Д. Линде. Вместе с последователями и учениками он организовал центр, где успешно помогает решать психологические проблемы своим разработанным методом эмоционально-образной терапии. Этот метод позволяет быстро и эффективно избавлять людей от разнообразных психосоматических проблем, фобий, депрессии, последствий стресса и т. д. Н. Д. Линде ведет достаточно активную работу в сфере психологии, изданные им учебники по психологическому консультированию, основам психотерапии используются и в учебном процессе как базовые в МосГУ.

В настоящее время Г. Г. Филиппова сократила свою нагрузку до минимума и ее можно понять. Г. Г. Филиппова - основатель отечественной психологии материнства. Она сотрудничает со многими вузами страны, ее действительно знают в России. Поражают ее организаторские способности. Вице-президент Российской Ассоциации Перинатальной Психологии и Медицины, член Президиума Межрегиональной ассоциации перинатальной психологии и медицины, руководитель секции перинатальной психологии Российского психологического общества и Московской секции перинатальной психологии РПО, ученый секретарь секции перинатальной психотерапии и психологии и психологии репродуктивной сферы Общероссийской Профессиональной Психотерапевтической Лиги, преподаватель Общероссийской Профессиональной Психотерапевтической Лиги межрегионального уровня, главный редактор научно-практического журнала «Перинатальная психология и психология репродуктивной сферы». Она успешно руководит аспирантами. Среди них талантливый молодой ученый И. А. Хватов, который после окончания нашего вуза и аспирантуры, также стал работать преподавателем на кафедре психологии развития и акмеологии, а затем и на кафедре общей психологии и истории психологии. Он автор ряда проектов, поддержанных грантами Президента РФ и РГНФ. По разному можно относиться к молодому дарованию, но сейчас канд. психол. наук И. А. Хватов является заведующим кафедрой общей психологии Московского государственного психолого-педагогического университета и заведующим научно-образовательным центром биопсихологических исследований Московского института психоанализа. Он нашел своего наставника в науке - это д-р психол. наук А. В. Барабанщиков.

Из прежнего состава той кафедры психологии личности и педагогики, с которой начинался факультет психологии, нас осталось трое. Среди них канд. психол. наук Н. В. Гребенникова. Она пришла в наш коллектив в 1997 г. сначала как штатный совместитель, затем уже А. В. Иващенко уговорил ее оставить государственный вуз и прийти к нам в штат. Н. В. Гребенникова - известный специалист в области клинической психологии. Можно привести один факт из ее профессиональной жизни. Когда у первого президента России Б. Н. Ельцина родился внук, и возникло подозрение относительно психического развития ребенка, для консультации была приглашена Н. В. Гребенникова. Это удивительно скромный человек, с повышенной чувствительностью к людям, готовностью прийти на помощь. Несмотря на внешнюю хрупкость, беззащитность, есть у нее внутренняя стойкость, надежность в работе и в отношениях. Она успешно руководит диссертационными исследованиями аспирантов, двое из ее подопечных остались работать в университете. Это канд. психол. наук Е. Г. Суркова и канд. психол. наук Н. И. Федотова. Н. В. Гребен- 
никова, несмотря на свой возраст, успешно осваивает новые технологии обучения. Она разработала и опубликовала пакет тестов по курсу клиническая психология, освоила мультимедийные программы, разработала электронную версию курса. В настоящее время у нас с Н. В. Гребенниковой появился общий научный интерес: проблема инклюзивного образования (Гребенникова, 2016). Н. В. Гребенникова читает курс по основам инклюзивного обучения, у меня же есть практический опыт обучения студентов с ограниченными возможностями здоровья.

Все сложности становления факультета, реорганизаций кафедр прошла вместе со мной еще одна моя коллега канд. психол. наук Т. С. Леви. Она пришла на кафедру психологии и педагогики в 1992 г., получив психологическую подготовку в МГУ, и стала читать психологические курсы на факультете социальной работы. Сфера ее научных интересов была уже определена и не менялась за все это время. Т. С. Леви целенаправленно работала над проблемой психологических границ личности, сейчас она завершает работу над докторской диссертацией, в рамках которой разработана пространственно-телесная модель развития личности. Создана методика диагностики психологических границ личности (Леви, 2008), есть авторский мастер-класс, который она успешно реализует на разных площадках Москвы. Она практикующий психолог, что позволяет ей привносить в читаемые курсы много примеров из жизни. Она оказалась и прекрасным организатором. Многие коллеги помнят конференцию, организованную Т. С. Леви по проблеме психологии телесности (Леви, 2005). Она сумела собрать и подготовить к печати уникальную хрестоматию по этой проблеме. Именно Т. С. Леви предложила мне разрабатывать проблемы геронтопсихологии. И сейчас это оказалось очень востребованным курсом.

Не могу не сказать несколько теплых слов о коллегах, с которыми сейчас работаю на одной кафедре. Прежде всего, надо отметить, что здесь нет случайных людей. Это профессионалы своего дела. Несмотря на то, что многие вынуждены работать в нескольких учебных заведениях, тем не менее, они преданы университету. Что удерживает коллег, в том числе и меня? Особый психологический климат на кафедре. Это также можно сказать в целом и про факультет. Атмосфера доверия и уважения, это здоровые взаимоотношения, основанные на принципах сотрудничества, взаимной помощи и поддержки, это доброжелательность и социальный оптимизм коллег, это взаимное расположение и понимание. Нет соперничества, конфликтов, нет группировок, нет борьбы за нагрузку. Уверена, что во многом это заслуга Ю. Н. Олейника. Теперь уже с позиции своего возраста, жизненного опыта и опыта работы в разных учебных заведениях, понимаю, что создавать коллектив, мобилизовать его на продуктивную деятельность можно по-разному. Стиль руководства коллективом во многом определяется личностными качествами руководителя. Он смог в свое время собрать в единую команду ведущих психологов, в сложных экономических условиях удерживать на кафедре многих из них, поддерживать связь с лабораториями ИП РАН, обновлять кадры за счет молодежи. Кроме этого, Ю. Н. Олейник и сам известный ученый в области истории отечественной психологии, психология личности и индивидуальности. У него есть широко известные научные публикации и учебники (Олейник, 1997, 2008). В качестве руководителя и в составе творческих коллективов неоднократно участвовал в научно- 
исследовательских грантах Российского гуманитарного научного фонда (РГНФ). Им подготовлено 6 кандидатов наук по психологическим специальностям, он является член-корреспондентом Международной академии психологических наук. Ю. Н. Олейник имеет изобретения, дважды награждался серебряной медалью Главного комитета ВДНХ СССР за научные разработки, имеет Почетную грамоту Министерства образования РФ за многолетнюю научно-педагогическую деятельность и большой вклад в дело подготовки высококвалифицированных специалистов, награжден медалью РФ В память 850-летия Москвы (1997).

Одна из учениц Ю. Н. Олейника - кандидат психол. Н. Н. Е. Коренкова не только успешно читает ряд психологических курсов, но и выполняет обязанности его заместителя по учебной работе. Область научных интересов Н. Е. Коренковой психомоторика в структуре интегральной индивидуальности человека (Коренкова, 2005).

С момента создания факультета на кафедре работает д-р психол. наук В. А. Кольцова, известный психолог, заведующая лабораторией истории психологии и исторической психологии, заместитель директора ИП ИПРАН. С Ю. Н. Олейником у них сложился продуктивный творческий союз, основанный не только на общем интересе к истории психологии, но и на личных человеческих отношениях (Кольцова, Олейник, 1995). Более 20 лет В. А. Кольцова читала курс «История психологии». Ее лекции, безграничные познания и умение донести их до слушателей вызывали восхищение со стороны студентов. Она подготовила и вырастила себе замену, передав чтение курса своей ученице канд. психол. наук И. С. Алексеенко. Еще одна ее аспирантка канд. псих. н. И. Р. Федоркова также в настоящее время является доцентом кафедры. И. Р. Федоркова историк по первому образованию, область ее научных интересов русское купечество (Федоркова, 2015). И. Р. Федоркова работала в период обучения в аспирантуре и в деканате заведующей отделением. Под руководством В. А. Кольцовой выполнено на кафедре 6 диссертационных исследований. Сейчас В. А. Кольцова сосредоточена на работе с аспирантами, а также является руководителем производственной практики наших студентов на базе ИП РАН, открывая им уникальную возможность прикоснуться к архивным материалам института.

Есть на кафедре уникальный человек, наш старейший профессор, канд. мед. наук Н. Н. Самко. Он также стоял у истоков создания факультета, осваивать преподавательскую деятельность ему пришлось уже в зрелом возрасте. Он был руководителем одного из отделов Министерства здравоохранения, работал у нас совместителем. После ухода на пенсию пришел работать на кафедру уже в качестве штатного сотрудника. Интеллигентный, скромный, обаятельный человек, всегда старается держаться в тени. Хорошо владеет материалом читаемых курсов, требователен к студентам, внимателен к коллегам.

Особую роль играет на кафедре д-р мед. наук В. М. Звоников, специалист в области психофизиологии труда и обеспечения психофизиологической надежности человека в экстремальных условиях, исследователь экстраординарных способностей человека (Звоников, 2013). Военный человек, связанный с авиацией. С 1997 по 2006 гг. - руководитель Центра восстановительной медицины ЦКБ МПС (Отраслевого научно-практического центра психофизиологии труда НУЗ ЦКБ 1 
ОАО «РЖД»). Его приход на кафедру связан с непростой ситуацией реорганизации данного центра. Ю. Н. Олейник смог поддержать В. М. Звоникова в этот сложный период его жизни. Сейчас у них сложился крепкий дружеский союз. В. М. Звоников является его заместителем по научной работе, руководителем программы подготовки магистров. Их добрые отношения друг к другу просматриваются во всем. Благодаря их усилиям при кафедре была создана лаборатория экспериментальной психофизиологии, которую возглавил В. М. Звоников.

Работая на одной кафедре, порой не догадываешься, какого масштаба с тобой рядом находится человек. Вячеслав Михайлович - скромный человек, он не любит рассказывать о своих прошлых заслугах. Праздник в честь его 70-летия открыл для меня и многих моих коллег уровень этого ученого. Более 43 лет изучает и развивает экстраординарные способности человека. Занимался психологией поведения человека в экстремальных ситуациях, психологическим отбором и подготовкой лиц опасных профессий: сотрудников спецслужб, космонавтов, летчиков, железнодорожников. Принимал участие как исследователь и врачиспытатель в острых многосуточных экспериментах (лишение сна, выживание в тайге и пустыне, пребывание в условиях полной изоляции и т. д.), организатор и активный участник научных экспедиций по исследованию возможностей человека в Тибете, Венесуэлле, Перу. Очень много добрых слов было сказано в его адрес коллегами, с которыми он вместе работал в разные годы своей жизни. Уровень его знаний, эрудиция, системное видение проблемы особо ярко проявляются на обсуждении диссертационных исследований аспирантов кафедры. С ним легко общаться, он всегда выдержан, спокоен, при этом обладает развитым чувством юмора. За время работы на кафедре под его руководством выполнено 6 диссертационных исследований. Большинство его бывших аспирантов продолжают с ним сотрудничать до настоящего времени.

Остаются работать на кафедре и специалисты из ИП РАН, среди них канд. психол. наук Т. Н. Савченко, заведующая лабораторией «Математической психологии». Она также была у истоков создания факультета, вместе с нами уже более 25-ти лет. Т. Н. Савченко преподает у нас дисциплины математического профиля. Область ее научных интересов - проблема качества жизни (Савченко, 2010). Как и многие другие, она не перестает удивляться, что так долго работает в МосГУ, при этом всегда подчеркивает, что делает это только из-за хорошего отношения к Ю. Н. Олейнику.

Когда-то Ю. Н. Олейник сделал ставку на аспирантов и выпускников, и это сейчас приносит плоды: И. Р. Федоркова, Н. Е. Коренкова, Н. В. Каргина, Е. Васильева, И. Н. Елисеева, А. И. Полянский, Е. Овчинников, В. Е. Степанова, Д. Д. Кожевников - все они психологи по образованию, но сумели овладеть сложной педагогической профессией. Они создают особую атмосферу на кафедре, очень дружны между собой. Факультет их не отпускает. Некоторые пытались работать в других организациях, но вернулись в свою альма-матер. Глядя на них, испытываешь чувство гордости, что ты тоже причастна к их становлению.

Нельзя не вспомнить и про наших методистов. Ю. Н. Олейнику удается подбирать на эту должность людей особых, неравнодушных, но при этом с хорошими деловыми качествами. И уже стало закономерностью, что потом они оказывают- 
ся на работе в разных структурах университета. Сейчас у нас работает Екатерина Фролова, и нам снова повезло. Спокойна, организована, внимательна, пунктуальна, коммуникабельна, исполнительна, скромна и тактична - это все про нее.

Есть много критериев оценки эффективности работы кафедры. Один из них - показатель подготовки кадров высшей квалификации. Всего за период с 1985 по 1992 гг. на кафедре педагогики и пионерской работы, кафедре психологии, педагогики и детского движения, кафедре психологии и педагогики было подготовлено 85 аспирантов. В основном это были исследования по специальности 13.00.01 - 75 человек; по специальности 19.00.05 - 8 человек и по специальности 19.00.11 - психология личности - 2 человека. В последующие годы на кафедрах факультета психологии прошли подготовку и успешно защитили диссертационные исследования 221 человек. Из них по специальности 13.00 .01 - 87 человек (из них 5 докторских диссертаций); по специальности 19.00.05 - 32 человека; по специальности 19.00.01 - общая психология, психология личности, история психологии - 102 человека.

На этом можно завершить историю кафедры психологии, педагогики и детского движения, которая прошла несколько этапов становления и развития. Думаю, что каждый из них имеет большое значение, как в жизни кафедрального коллектива, так и в деятельности вуза в целом. Искренне желаю кафедре общей психологии и истории психологии сохраниться самой как подразделение университета и сохранить свой человеческий потенциал.

\section{СПИСОК ЛИТЕРАТУРЫ}

Гребенникова, Н. В., Федотова, Н. И. (2010) Особенности представлений о будущей семье у детей - сирот // Современная российская семья: традиции и альтернативы Сборник научных статей Всероссийской научно-практической конференции. М. : Московский психолого-социальный институт, филиал в Муроме. С. $134-139$.

Гребенникова, Н. В. (2007) Клиническая психология. Тесты. М: Московский гуманитарный университет. 167 с.

Гурова, Е. В. (2005) Психология развития и возрастная психология. Тесты. М. : Аспект -Пресс. 174 с.

Гурова, Е. В. Гребенникова, Н. В. (2016) Инклюзия в вузе: проблема готовности преподавателей // Высшее образование для XXI века: XIII Международная научная конференция. Москва, 8-10 декабря 2016 г.: Доклады и материалы. Секция 4. Психологические проблемы образования / отв. ред. А. Л. Журавлев. М. : Изд-во Моск. гуманит. ун-та. С. 45-49.

Гурова, Е. В., Суркова, Е. Г. (2012) Способность к творческой самореализации молодых людей с различной сиблинговой позицией в семье // Знание. Понимание. Умение. № 4. С. 285-288. 
Звоников, В. М. (2013) Особенности динамики функциональных ассиметрий человека в условиях воздействия хронического стресса // Вестник восстановительной медицины. № 1. С. 108-115.

Кольцова, В. А., Олейник, Ю. Н. (1995) Работа советских психологов в годы великой отечественной войны // Психологический журнал. № 3. Т. 16. С. 3-12.

Коренкова, Н. Е. (2005) Психомоторика в структуре интегральной индивидуальности человека : учеб. пособие. М. : Московский гуманитарный университет.

Леви, Т. С. (2005) Межведомственная научно-практическая конференция «Междисциплинарные проблемы психологии телесности» // Знание. Понимание. Умение. № 1. С. 180-181.

Леви, Т. С. (2005) Межведомственная научно-практическая конференция «Междисциплинарные проблемы психологии телесности» // Знание. Понимание. Умение. № 1. С. 180-181.

Леви, Т. С. (2008) Отношение к телу в структуре самоотношений // Знание. Понимание. Умение. № 3. С. 72-75.

Олейник, Ю. Н. (2008) Периодизация истории психологии: проблемы и перспективы // Методология и история психологии. Т. 3. № 2. С. 25-32.

Психология семьи (2014): учебник для студ. учреждений высш. проф. образования / Н. В. Гребенникова, Е. В. Гурова, Е. И. Захарова и др.; под ред. Е. Г. Сурковой. М. : Издательский центр «Академия». 240 с.

Савченко, Т. Н. (2010) Методология исследования субъективного качества жизни // Прикладная юридическая психология. № 4. С. 23-35.

Суркова Е. Г. (2008) Проективные методы диагностики : Психологическое консультирование детей и подростков : учебное пособие для студентов вузов. М.: Аспект-Пресс. 319 с.

Федоркова, И. Р. (2015) Особенности менталитета русского купечества конца XIX начала XX столетия // Историогенез и современное состояние российского менталитета. М. Издательство ИПРАН. С. 302-320.

Дата поступления: 15.02.2018 г.

Гурова Елена Васильевна - кандидат педагогических наук, профессор кафедры общей психологии и истории психологии Московского гуманитарного университета. Адрес: 111395, Россия, г. Москва, ул. Юности, д. 5. Тел.: + 7 (499) 37467-20. Эл. адрес: opsy@mail.ru

Gurova Elena Vasilyevna, Candidate of Pedagogy, Professor of Department of General Psychology and History of Psychology of Youth, Moscow University for the Humanities. Postal address: 5, Yunosti Str., Moscow, Russian Federation 111395. Tel.: +7 (499) 374-67-20. E-mail: opsy@mail.ru 


\section{Для цитирования:}

Гурова Е. В. От кафедры пионерской работы до кафедры общей психологии и истории психологии (из истории факультета психологии, педагогики и социологии Московского гуманитарного университета) [Электронный ресурс] // Научные труды Московского гуманитарного университета. 2018. № 1. URL: http://journals.mosgu.ru/trudy/article/ view/676 (дата обращения: дд.мм.гг.). DOI: 10.17805/trudy.2018.1.1 